\title{
DETERMINATION OF METAL CONTENT AND AN ASSESSMENT OF THE POTENTIAL USE OF WASTE CASHEW NUT ASH (CNSA) AS A SOURCE FOR POTASH PRODUCTION
}

\author{
Mary B. Ogundiran, ${ }^{*, a}$ Joshua O. Babayemi, ${ }^{*}$, and Chima G. Nzeribe ${ }^{\text {a }}$ \\ The potential use of waste cashew nut shell (CNS) ash as a source for \\ potash production was investigated in this study. Managing waste ash \\ generated from cashew nut processing is a major challenge, as land \\ filling and open dumping of the waste ashes have been the main options \\ in management of the ash in Nigeria. Economically viable ways of using \\ waste ash rather than having to dispose of it have to be investigated. \\ The CNS was air-dried for 4 weeks and combusted to ashes; the \\ resulting ash was extracted with water for its potash content. Some \\ parameters of the CNS, including moisture, dry matter, and ash content, \\ were determined. Potash yield obtained was $33.4 \%$ of $150 \mathrm{~g}$ CNS ash \\ used; analysis of the potash gave it a percentage purity of $78 \%$, while \\ purity on recrystalization increased to $86 \%$. Potash yield from CNS ash \\ was comparable to those reported for wood ash, plantain peels, and \\ other agro-wastes. Also, the results showed that the CNS shared similar \\ lignocellulosic properties and characteristics with hardwood biomass.
}

Keywords: Ash; Alkali; Potash; Cashew nut shell

Contact information: Contact information: a: Department of Chemistry, Faculty of Science, University of Ibadan, Nigeria; b: Department of Chemical Sciences, Bells University of Technology, Ota, Nigeria. "Corresponding author: mbogundiran@yahoo.com; +2348023309861; babayemola@yahoo.co.uk; $+2348060709930$

\section{INTRODUCTION}

Cashew (Anacardium occidentale) is one of the Nigeria's leading cash crops, being the world's $2^{\text {nd }}$ largest producer of cashew. Nigeria produces 636,000 tons of cashew nuts yearly (FAO, 2008), most of which is for the export market. The cashew nuts are exported either as whole shell or they are processed; and the cashew kernel is exported. Agricultural and agro-industrial waste accumulates as a result of the activities of cashew processing industries; this is largely due to the location of such industries near the raw materials, and the location of farms and plantations in rural areas. This contributes to the present problems of environmental pollution, as government attention is mostly focused on cities and towns. Agro-waste or plant biomasses in Nigeria are mostly subjected to open-air burning with its attendant environmental implications (Babayemi and Dauda 2009). These wastes could be efficiently managed if used for other viable industrial, agricultural, or domestic purposes, thereby reducing the problem of environmental pollution and also creating wealth.

Cashew processing industries generate the cashew nut shell as a waste product; they utilize the waste cashew nut shell as a source of heat, especially in Nigeria where the 
public energy supply is erratic and dependence on diesel fuel is costly. The perennial nature of the crop means that there is an abundance of waste cashew nut shell at the peak of the season; most processing industries resort to dumping of the excess waste cashew nut shell on open land and indiscriminate burning. Use of plant biomass as source of energy offers a cheap, environmentally friendly alternative to the conventional petroleum energy sources. Energy generation from biomass such as tree bark, wood residues, and other plant materials produces a considerable amount of fly and bottom ashes. Managing waste ash generated from cashew nut processing is a major challenge, as land filling and open dumping are the main options in management of the waste ash.

It was reported that potash production provided early North American settlers with the badly needed cash as they cleared their wooded land for crop production and cleared tree stumps. The cleared wood needed to be disposed of, and the easiest way to accomplish this was to burn any wood not needed for fuel or construction. Ashes from hardwood trees could then be used to make lye, which could be used to make soap or boiled down to produce valuable potash. Exploration of ash-derived alkalis for domestic use is an ancient craft (Onyegbado et al. 2002; Nwoko 1982) involving simple technology and chemistry (Babayemi et al. 2010a). The general principles in potash production from ashes involved leaching the ashes with water; the 'leachate' is then evaporated. The residue is the crude potash. The quality of the residue depends on the materials used, as well as procedure and equipment. Babayemi et al. (2010a) report the details. Materials for ashes in potash production such as wood (Adewuyi et al. 2008; Babayemi and Adewuyi 2010), banana and plantain peels (Babayemi et al. 2010b; Onyegbado et al. 2002; Ankrah 1974), cocoa pod husk (Afrane 1992), palm bunch (Kuye and Okorie 1990), cassava peels (Onyekwere 1996), and livestock dung (Babayemi et al. 2010c) have been investigated. The limitations to the use of some of these materials include low potash yield. Furthermore, some of those which give high potash yield are not available throughout the year.

Economically viable ways of using waste ash rather than having to dispose of it have to be investigated. There is already a vast body of information on utilization of fly ash (FA) in building/construction, production of aggregates and more recently for agriculture (Brian et al. 2003).

This study therefore seeks to find potential use for waste ash residue of cashew nut shell (CNS) as a source of potash.

\section{EXPERIMENTAL}

\section{Sample Collection and Treatment}

The CNS, which were not yet burnt, were collected at a point from the dump site of a cashew nut processing plant in Olowopokun, Iseyin, Nigeria. The waste CNS was sun-dried for 4 weeks, and then ashed.

Determination of Moisture Content (MC), Dry Matter Content (DM) and Density of the Samples (DS)

A known weight $\left(W_{1}\right)$ of air-dried cashew nut shell sample was taken and oven- 
dried at $105{ }^{\circ} \mathrm{C}$ for 3 hours (Radojevic and Bashkin 2005). It was transferred into a desicator to cool and then weighed $\left(W_{2}\right)$. Calculations were carried out as follows,

$$
\begin{aligned}
& M C=\left[\left(W_{1}-W_{2}\right) / W_{1}\right] \times 100 \% \\
& D M=\left(W_{2} / W_{1}\right) \times 100 \% \\
& D S=\left(W_{2} / V_{1}\right)\left(\mathrm{gmL}^{-1}\right)
\end{aligned}
$$

where $V_{1}$ is the volume of quantity of $\left(W_{2}\right)$ determined. Duplicate determinations were carried out.

\section{Ash Content $(A C)$, Loss in Weight ( $L W)$, and Density of Ashes (DA)}

A known weight $\left(W_{3}\right)$ of sample dried in the oven at $105{ }^{\circ} \mathrm{C}$ for 3 hours was combusted to ashes in a muffle furnace set at $500{ }^{\circ} \mathrm{C}$ for 4 hours using porcelain crucibles. After cooling, the weight $\left(W_{4}\right)$ of the ash residue was determined. The density of the ashes was determined with slight modification to GEA Niro Method No. A 2a (2006). The ash content was calculated using the following relationship,

$$
\begin{aligned}
& A C=\left(W_{4} / W_{3}\right) \times 100 \% \\
& L W=\left[\left(W_{3}-W_{4}\right) / W_{3}\right] \\
& D A=\left(W_{5} / V_{2}\right)\left(\mathrm{gmL}^{-1}\right)
\end{aligned}
$$

where $V_{2}$ is the volume of the quantity of ash $\left(W_{5}\right)$. Duplicate determinations were carried out.

\section{Extraction of Alkali from the Ash}

The method used followed that described by Adewuyi et al. (2008) in which both high quality and quantity of potash were said to be obtained, and the effectiveness of the method was comparable to other existing ones. $150 \mathrm{~g}$ of the waste CNS ash sample were placed in a 4-litre transparent plastic bottle. Two litres of distilled water were added; the mixture was covered and thoroughly shaken. It was allowed to stand for about 12 hours, hanging on a clamp on a retort stand. The lid was removed and a few pin holes were made at the bottom of the bottle using an injection needle. The extract solution leaked into a collecting bowl as it filtered through the ash sediment. 1.5 litres of the extract solution was evaporated to a smaller volume and then quantitatively transferred into a pre-weighted crucible in which evaporation to dryness was carried out. The crucible with its content was placed in the oven set at $105{ }^{\circ} \mathrm{C}$ for 3 hours. After cooling in a desicator, the weight $\left(W_{6}\right)$ of the potash in the crucible was determined using a Mettler balance.

The actual amount of potash from the $150 \mathrm{~g}$ of ashes was calculated as follows:

1.5 litre of extract solution contained $W_{6}$, then 2 litres of extract solution would contain $\left[\left(W_{6} X 2\right) / 1.5\right] \mathrm{g}=z(\mathrm{~g})$. Therefore, the percent potash yield is given by $(z / 150) X 100$.

Duplicate determination was carried out. 


\section{Determination of Purity of the Crude Potash}

$3.45 \mathrm{~g}$ of the crude potash were dissolved in water and made up to mark in a 250 $\mathrm{mL}$ standard flask. $10 \mathrm{~mL}$ was pipetted into a conical flask and then titrated with $0.1 \mathrm{M}$ hydrochloric acid, using methyl orange as indicator (Babayemi et al. 2010a). Five replicates were obtained, and duplicate analysis was carried out. The chemical reaction could be shown as:

$$
2 \mathrm{HCl}(\mathrm{aq})+\mathrm{K}_{2} \mathrm{CO}_{3}(\mathrm{aq}) \rightarrow 2 \mathrm{KCl}(\mathrm{aq})+\mathrm{CO}_{2}(\mathrm{~g})+\mathrm{H}_{2} \mathrm{O}(\mathrm{l})
$$

\section{Analysis of Carbonate and Hydroxide Content}

A double-indicator method was used in the acid-base titration analysis of the mixture of alkali hydroxide and carbonate (Ojokuku 2001). $10 \mathrm{~mL}$ of the sample solution was pipetted into a conical flask, 2 drops of phenolphthalein indicator was added, and the mixture was titrated with $0.1 \mathrm{M} \mathrm{HCl}$ until a colourless solution was obtained. At that point, the whole of the hydroxide and half of the carbonates had been titrated, giving a burette reading $v_{1}$. The equation of the reaction is as shown below:

$$
\begin{aligned}
& \mathrm{HCl}(\mathrm{aq})+\mathrm{KOH}(\mathrm{aq}) \rightarrow \mathrm{KCl}(\mathrm{aq})+\mathrm{H}_{2} \mathrm{O}(\mathrm{l}) \\
& \mathrm{HCl}(\mathrm{aq})+\mathrm{K}_{2} \mathrm{CO}_{3}(\mathrm{aq}) \rightarrow \mathrm{KCl}(\mathrm{aq})+\mathrm{KHCO}_{3}(\mathrm{aq})
\end{aligned}
$$

Methyl orange was added to the resulting colourless solution and titrated until the colour changed from yellow to orange. At that point, the remaining bicarbonate was neutralized by the acid; the burette reading now becomes $v_{2}$. The equation of the reaction is as follows:

$$
\mathrm{HCl}(\mathrm{aq})+\mathrm{KHCO}_{3}(\mathrm{aq}) \rightarrow \mathrm{KCl}(\mathrm{aq})+\mathrm{H}_{2} \mathrm{O}(\mathrm{l})+\mathrm{CO}_{2}(\mathrm{~g})
$$

\section{Calculations:}

Titre for neutralization of $\mathrm{KHCO}_{3}=v_{2}-v_{1}$

Titre for neutralization of $\mathrm{KOH}=v_{1}-\left(v_{2}-v_{1}\right)$

Titre for neutralization of $\mathrm{K}_{2} \mathrm{CO}_{3}=2\left(v_{2}-v_{1}\right)$

Assuming the average titre for neutralization of $\mathrm{KOH}, v_{1^{-}}\left(v_{2}-v_{1}\right)=x \mathrm{~mL}$, and that of $\mathrm{K}_{2} \mathrm{CO}_{3}, 2\left(v_{2}-v_{1}\right)=y \mathrm{~mL}$, then the molar concentration of $\mathrm{KOH}=0.1 \mathrm{X} x$

Therefore,

$$
\mathrm{KOH}=[0.56 x /(0.56 x+0.69 y)] \times 100 \%
$$

and

$$
\mathrm{K}_{2} \mathrm{CO}_{3}=[0.56 y /(0.56 x+0.69 y)] \times 100 \%
$$




\section{The Amount of $\mathrm{KOH}, \mathrm{K}_{2} \mathrm{CO}_{3}$, and Non-Alkali Contents}

The amount of $\mathrm{KOH}, \mathrm{K}_{2} \mathrm{CO}_{3}$, and non-alkaline contents of the crude potash were calculated as follows:

$$
\begin{aligned}
& \% \mathrm{KOH}=t \mathrm{X} \% \text { Purity of crude potash } \\
& \% \mathrm{~K}_{2} \mathrm{CO}_{3}=u \mathrm{X} \% \text { Purity of crude potash } \\
& \% \text { Non- alkali contents = } 100 \text { - \% Purity of crude potash }
\end{aligned}
$$

where $t$ and $u$ are the percentages of $\mathrm{KOH}$ compared to $\mathrm{K}_{2} \mathrm{CO}_{3}$ and percentage of $\mathrm{K}_{2} \mathrm{CO}_{3}$ compared to $\mathrm{KOH}$, respectively.

\section{Purification of Crude Potash}

The crude potash was re-dissolved in sufficient distilled water and heated gently until there was an appearance of precipitates, and then allowed to cool to room temperature. The less soluble components crystallized out on cooling; the remaining solution was decanted off and evaporated to dryness and finally to constant weight. The dried crystals were subjected to titrimetric analysis to determine the purity (Adewuyi et al. 2008).

\section{Analysis of Inorganic Elements}

$1 \mathrm{~g}$ of ground sample was weighed and placed in a beaker. $30 \mathrm{ml}$ of $1: 1 \mathrm{HNO}_{3}(10$ $\mathrm{mL}$ water $+10 \mathrm{~mL}$ concentrated $\mathrm{HNO}_{3}$ ) were added and boiled gently on a hotplate until the volume was reduced to approximately $5 \mathrm{~mL}$ while stirring. A further $10 \mathrm{~mL}$ of 1:1 $\mathrm{HNO}_{3}$ were added and the process repeated, it was cooled and the extract filtered through a Whatman no. 41 filter paper, and the filter paper and beaker were washed with successive $0.25 \mathrm{M} \mathrm{HNO}_{3}$ portions. The filtrate was transferred to a $50 \mathrm{~mL}$ volumetric flask and diluted to the mark with de-ionised water. The sample was analyzed by atomic absorption spectroscopy (Radojevic and Bashkin 2005) at $228.8 \mathrm{~nm}, 357.9 \mathrm{~nm}, 283.3 \mathrm{~nm}$, $324.7 \mathrm{~nm}, 248.3 \mathrm{~nm}, 213.9 \mathrm{~nm}, 422.7 \mathrm{~nm}, 766.5 \mathrm{~nm}, 285.2 \mathrm{~nm}$, and $589.0 \mathrm{~nm}$ for Cd, Cr, $\mathrm{Pb}, \mathrm{Cu}, \mathrm{Fe}, \mathrm{Zn}, \mathrm{Ca}, \mathrm{K}, \mathrm{Mg}$, and $\mathrm{Na}$, respectively.

\section{RESULTS AND DISCUSSION}

Table 1 shows the moisture $(M C)(12.4 \%)$, dry matter $(D M)(87.6 \%)$, ash $(A C)$ $(3.00 \pm 0.46 \%)$, and potash $(P C)(33.4 \pm 0.22 \%)$ contents, as well as the densities (DS) $(0.34 \mathrm{~g} / \mathrm{mL})$ of the CNS and of the resulting ash $(D A)(0.26 \mathrm{~g} / \mathrm{mL})$. The results of the titrimetry are shown in Table 2: the initial purity was $78 \%$ with the impurity (non-alkali) content of $22 \%$; and the final purity after recrystallization was $86 \%$ with an impurity (non-alkali) content of $14 \%$.

The amount of $\mathrm{KOH}(1.60 \%)$ compared to $\mathrm{K}_{2} \mathrm{CO}_{3}(98.4 \%)$ are shown in Table 3, while Table 4 shows the results of metal analysis. 
Table 1. Physical Parameters, Ash, and Potash Contents of CNS

\begin{tabular}{|l|l|}
\hline Parameters & Value \\
\hline MC $(\% \mathrm{w} / \mathrm{w})$ & 12.4 \\
\hline DM $(\% \mathrm{w} / \mathrm{w})$ & 88.6 \\
\hline DS $(\mathrm{g} / \mathrm{mL})$ & 0.34 \\
\hline DA $(\mathrm{g} / \mathrm{mL})$ & 0.26 \\
\hline LW $(\% \mathrm{w} / \mathrm{w})$ & 97.0 \\
\hline AC $(\%)$ & $3.00 \pm 0.46^{*}$ \\
\hline PC $(\%)$ & $33.4 \pm 0.22^{*}$ \\
\hline $\begin{array}{l}\text { MC: moisture content; DM: dry matter content; } \text { DS: density of sample; DA: } \\
\text { density of ash; LW: loss in weight. } \pm \text { SD* }^{*} \mathrm{n}=4\end{array}$ \\
\hline
\end{tabular}

From the results of the physical parameters, one may infer that CNS shares similar characteristics with hardwood biomass (Bingh 2004). Ash yield was low, as is usually the case with most woody biomass, and this explains why a large quantity of CNS yielded only little quantity of ash. Potash yield was moderate, but higher than those (2.77 to 26.88\%) reported for several African wood species (Adewuyi et al. 2008). The percentage purity (78\%) determined for CNSA here is high, compared with those reported in the literature: 12.40 to $56.73 \%$ for various agro-wastes (Taiwo and Osinowo 2008), 4.50 to $95.50 \%$ for wood species (Adewuyi et al. 2008), and 69.00 to $81.90 \%$ for musa species (Babayemi et al. 2010b); however, the value falls within the range of those in the references. There was an increase in purity on recrystalization (from 78 to $86 \%$ ). The result of duplicate analysis showed no significant difference: $t$-calculated $=3.464$ while the critical value $=4.520$ at $95 \%$ confidence level.

Table 2: Average Titre Value, Concentration and Purity of Crude Potash and Purity on Recrystalization.

\begin{tabular}{|l|l|l|l|}
\hline Average titre $(\mathrm{mL})$ & Concentration $\left(\mathrm{mol} / \mathrm{dm}^{3}\right)$ & Purity $(\%)$ & Non-alkali (\%) \\
\hline 14.1 & $7.84 \times 10^{-2}$ & 78 & 22 \\
\hline \multicolumn{4}{|c|}{ RECRYSTALIZATION } \\
\hline 18.2 & $0.09 \quad 86$ & 14 \\
\hline
\end{tabular}

The higher amount of $\mathrm{K}_{2} \mathrm{CO}_{3}$ compared to $\mathrm{KOH}$ suggests that the potash obtained was predominantly potassium carbonate. However, the significant amount of soluble nonalkali content observed implies the presence of other soluble salts than $\mathrm{K}_{2} \mathrm{CO}_{3}$.

Table 3. Amount of $\mathrm{KOH}$ Compared to $\mathrm{K}_{2} \mathrm{CO}_{3}$ Expressed as a Percentage

\begin{tabular}{|l|l|l|}
\hline & $\mathrm{KOH}(\%)$ & $\mathrm{K}_{2} \mathrm{CO}_{3}(\%)$ \\
\hline CNS Ash & 1.60 & 98.4 \\
\hline
\end{tabular}

In the results of analysis of heavy metals ( $\mathrm{Cd}, \mathrm{Cr}, \mathrm{Pb}, \mathrm{Cu}, \mathrm{Fe}$, and $\mathrm{Zn}$ ), Fe had the highest value $(7937 \mathrm{mg} / \mathrm{kg})$, while Cd showed the least concentration $(1.5 \mathrm{mg} / \mathrm{kg})$. Macro-element analysis of the CNS ash (Ca, K, Mg, and $\mathrm{Na}$ ) indicated the least concentration of $1.8 \mathrm{~g} / \mathrm{kg}$ for $\mathrm{Na}$, while $\mathrm{Ca}$ had the highest $(38.7 \mathrm{~g} / \mathrm{kg})$. Generally, the values were higher than those in the references (Misra et al. 1993; Babayemi et al. 2010b), perhaps because this is a different species of plant, and analyzing the nut in particular. 
Table 4. Concentrations of Nutrient and Heavy Metals in CNS Ash

\begin{tabular}{|l|l|}
\hline \multicolumn{2}{|c|}{ Heavy metals (mg/kg) } \\
\hline $\mathrm{Cd}$ & $1.50 \pm 0.01$ \\
\hline $\mathrm{Cr}$ & $53.1 \pm 0.14$ \\
\hline $\mathrm{Pb}$ & $142 \pm 0.26$ \\
\hline $\mathrm{Cu}$ & $80.4 \pm 0.16$ \\
\hline $\mathrm{Fe}$ & $7940 \pm 5.00$ \\
\hline $\mathrm{Zn}$ Nutrients $(\mathrm{g} / \mathrm{kg})$ & $726 \pm 1.16$ \\
\hline $\mathrm{Ca}$ & 38.7 \\
\hline $\mathrm{K}$ & 2.70 \\
\hline $\mathrm{Mg}$ & 2.20 \\
\hline $\mathrm{Na}$ & 1.80 \\
\hline Triplicate analysis $( \pm \mathrm{SD}, \mathrm{n}=3)$ \\
\hline
\end{tabular}

\section{CONCLUSIONS}

1. The high potash yield of the cashew nut shell shows that it has a potential use as a source of materials for potash production; and there is the possibility of improving the purity of the potash by recrystalization.

2. However, bioaccumulation of heavy metals in the plant may be inferred, and this perhaps may have effects on the chemistry of potash arising from this source. Further work is suggested to verify this.

\section{REFERENCES CITED}

Adewuyi, G. O., Obi-gbedi, N. O., and Babayemi, J. O. (2008). "Evaluation of ten different African wood species for potash production,” International Journal of Physical Sciences 3(3), 63-68.

Afrane, G. (1992). “Leaching of caustic potash from cocoa husk ash,” Bioresource Technology 41(2), 101-104; DOI: 10.1016/0960-8524(92)90177-Y.

Ankrah, E. A. (1974). "Chemical studies of some plant wastes from Ghana,” Journal of the Science of food and Agriculture 25(10), 1229-1232; DOI: 10.1002/jsfa.2740251006

Babayemi, J. O., and Adewuyi, G. O. (2010). “Assessment of combustion and potash production as options for management of wood waste," Journal of Applied Sciences and Environmental Management 14(1), 73-75.

Babayemi, J. O., and Dauda, K. T. (2009). "Evaluation of solid waste generation, categories and disposal options in developing countries: A case study of Nigeria," Journal of Applied Sciences and Environmental Management 13(3), 83-88.

Babayemi, J. O., Dauda, K. T., Kayode, A. A. A., Nwude, D. O., Ajiboye, J. A., Essien, E. R., and Abiona, O. O. (2010b). "Determination of potash alkali and metal contents of ashes obtained from peels of some varieties of Nigeria Grown Musa species," BioResources 5(3), 1384-1392. 
Babayemi, J. O., Dauda, K. T., Nwude, D. O., and Kayode, A. A. A. (2010a). "Evaluation of the composition and chemistry of ash and potash from various plant materials - A review,” Journal of Applied Sciences 10(16), 1820-1824.

Babayemi, J. O., Ololade, Z. S., Onipede, O. J., and Dauda, K. T. (2010c). "Evaluation of livestock dung for potash alkali and metal contents," Proceedings of the Chemical Society of Nigeria $33^{\text {rd }}$ Annual International Conference, Workshop \$ Exhibition on Green Chemistry and Sustainable Development (Challenges and Prospects), held at Kuto, Abeokuta, $20^{\text {th }}-24^{\text {th }}$, September, 2010.

Bingh, L. P. (2004). “Opportunities for utilizing waste biomass for energy in Uganda,” M.Sc. Dessertion thesis, NTNU, Sweden.

Brian, R. H., Hayden, D. B., and Powell, M. A. (2003). "Evaluation of pulverized fuel ash mixed with organic matter to act as a manufactured growth medium," International Ash Utilization Symposium., Centre for Applied Energy Research, Univ. of Kentucky.

Food and Agricultural Organization of United Nations (2008). Economic and Social Department: The Statistical Division.

GEA Niro Analytical Method No. A 2a (2006). Powder Bulk Density.

Kuye, A. O., and Okorie, C. (1990). "Factors affecting the lixiviation of palm bunch ash as a source of alkali for soap production,” Ife J. Technol. 3, 33-37.

Misra, M. K., Ragland, K. W., and Baker, A. J. (1993). "Wood ash composition as a function of furnace temperature,” Biomass Bioenergy 4, 103-116.

Nwoko, V. O. (1998). “Chemical processing development,” Proceedings of the $10^{\text {th }}$ Annual Conference of the Nigerian Society of Engineers, pp. 40-53.

Ojokuku, G. O. (2001). "Use of double indicators in acid-base titration analysis of a mixture of $\mathrm{NaOH}$ and $\mathrm{Na}_{2} \mathrm{CO}_{3}$," Practical Chemistry for Schools and Colleges, pp. 40-53.

Onyegbado, C. O., Iyagba, E. T., and Offor, O. J. (2002). "Solid soap production using plantain peels ash as source of alkali,” Journal of Applied Sciences and Environmental Management. 6(1), 73-77.

Radojevic, M., and Bashkin, V.N. (1999). "Plant analysis,” Practical Environmental Analysis 379-397.

Taiwo, O. E., and Osinowo, F. A. O. (2001). "Evaluation of various agro-waste for traditional soap production,” Bioresource Technology 79(1), 95-97.

Article submitted: October 19, 2010; Peer review completed: December 20, 2010; Revised version received and accepted: December 24, 2010; Published: December 28, 2010. 